\title{
京都市街地都市林におけるアオバズクの生息環境適合 度モデル
}

\author{
Habitat Modeling for the Brown Hawk Owls in Urban Woods of Kyoto City
}

橋本 啓史 ${ }^{*}$ 澤 邦之** 森本 幸裕 ${ }^{* * *}$ 西尾 伸也****

Hiroshi HASHIMOTO Kuniyuki SAWA Yukihiro MORIMOTO Shinya NISHIO

\begin{abstract}
Brown Hawk Owl (Ninox scutulata) is a migratory insectivorous bird which breeds in tree cavities, and a target species for old woods in urban areas of Japan. Population of the owl is decreasing recently because of diminishing of old woods in Japan and also in tropical rain forests: their habitats during non-breeding season. A habitat model using statistical methods is a good tool to answer the question how much forest is required for conservation of a target species. We made a habitat model for the owl using a logistic regression model. We searched for owls by examining almost every large tree with cavities in a $25 \mathrm{~km}^{2}$ urban area in Kyoto City during the breeding season (May to July) of 2002. Fourteen trees determined to be habitats of owls and 15 trees with cavities but without nests were found. Applying logistic regression analysis with the stepwise method and AIC, the area of tree cover and the area of urbanized area within a radius of $100 \mathrm{~m}$ were determined to be variables for the habitat model of the owl. From the result, at least 1.1 ha of woods including an old tree with a cavity is necessary for conservation of the owl habitat.
\end{abstract}

Keywords: Brown Hawk Owls, birds, habitat model, urban greenery, urban woods キーワード：アオバズク，鳥類，ハビタットモデル，都市緑地，都市林

1.はじめに

アオバズク Ninox scutulata はフクロウ科の夜行性の猛禽類 で, 東南アジアの熱帯多雨林で越冬し, 日本には繁殖のために初 夏に飛来して, 都市や農村, 山地の森林にある巨木の樹洞に営巣 する。主な餌は甲虫や蛾, 七ミであるが, 小鳥や小型哺乳類, 爬 虫類を捕食することあある ${ }^{13), 16,17), 18)}$ 。社寺林が多く残る京都市で は比較的多くのアオバズクが繁殖していたが ${ }^{18)}$, 近年, 営巣でき る巨木の減少 ${ }^{6)}$ や越冬地の熱帯多雨林の破壊 ${ }^{4)}$ によって本種の個 体数は全国的に減少傾向にあり，近畿地区鳥類レッドデータブッ ク ${ }^{1)}$ や京都府レッドデータブック ${ }^{6)}$ では準絶滅危惧種に指定され ている。京都の社寺林は駐車場化などによって年々面積が減少し ており，アオバズクの生息可能な樹林面積を明らかにすることが， 本種の保全にとって不可欠である。1970 年代に静岡市内の社寺 林でアオバズクの生息地が調べられた例では, 樹林面積 0.01 〜 4.0ha の社寺林で生息していたことが報告されているが 囲の樹木率などとの関係については定量的に明らかにされていない。

本研究では, アオバズクの生息の有無を目的变数, 樹冠面積・ 市街地面積・大木数・樹洞を有する木の数などの環境条件を説明 变数にしたアオバズクの生息環境適合度モデルを作成し, 生息環 境を明らかにして，本種の保全のあり方を提言することを目的と した。2002 年に環境省によって策定された『新・生物多様性国 家戦略』の「グランドデザイン」の中で, 「都市にも巨木がそび え，大都市にも大きな森があり，猛禽類が悠々之空を舞っている。」 という都市像が示されている。アオバズクの生息環境を保全・創 出することは, まさにこの都市像を実現することと言えよう。都 市において巨木を有する緑地は生物多様性保全の核となる緑地で あり, 生息環境適合度モデルによってアオバズクの生息に必要な 樹林面積を提示することで具体的な保全面積の検討が可能となる。

\section{2. 調査地および方法} (1) 現地調査
調査範囲は京都市東部の山麓から京都御苑を含む市街地にかけ ての約 $5 \mathrm{~km}$ 四方, 約 $25 \mathrm{~km}$ の範囲である (図 -1 )。京都市街地に は比較的自然状態に近い孤立林がいくつむ残されており, 村上ら によって木本植物相 ${ }^{10)}$ やシダ植物相 ${ }^{9)}$ が報告されている。また,

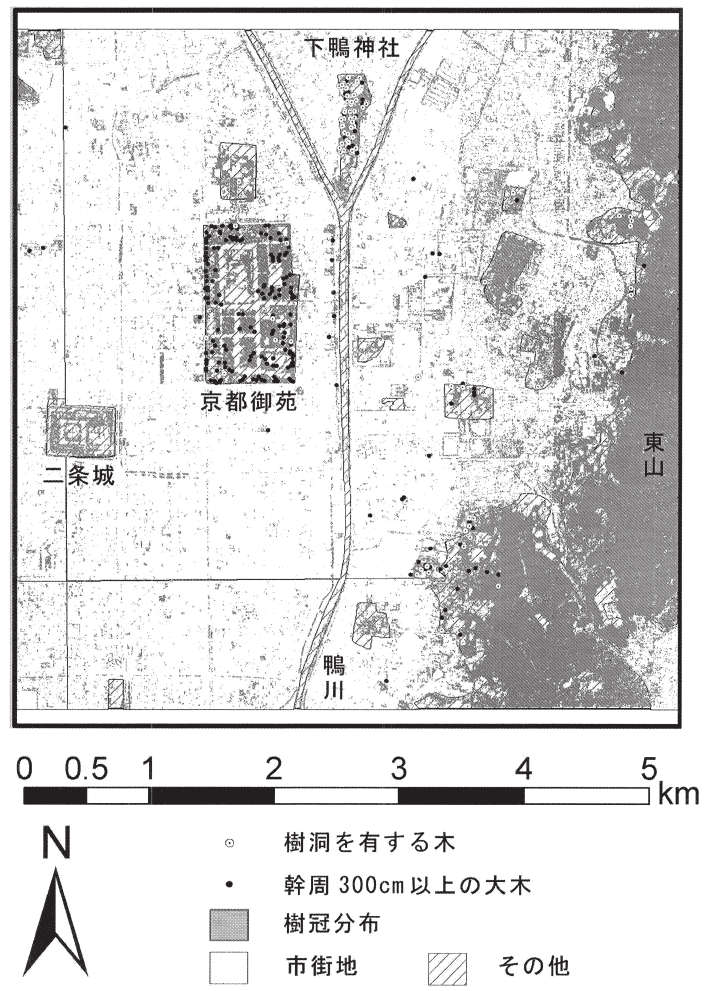

図ー 1 調査地の範囲および樹冠・市街地・大木の分布

*京都大学大学院農学研究科 $* *$ 京都大学農学部 $* * *$ 京都大学大学院地球環境学堂 $\quad * * *$ 清水建設株式会社技術研究所 
市街地の各地にニレ科の大木が残されている ${ }^{15,19}$ 。本研究では, 自然的な樹林か否かに関わらず，調查範囲内全域の樹木を対象之 し, アオバズクの出入り可能な入り口直径が約 $10 \mathrm{~cm}$ 以上の樹洞 (巣箱では入り口直径が $9-10 \mathrm{~cm}$ とされる ${ }^{14)}$ ) を有する木の位置 を調べた。また, 胸高幹周 $300 \mathrm{~cm}$ 以上の大木の位置を, 京都市 「区民の誇りの木」事業で選定された樹木や環境庁の第 4 回自然 環境保全基礎調査「巨樹・巨木林」調査の情報を参考に調査し, これらの大木については全て樹洞の有無も記録した。

2002 年のアオバズクの繁殖期である 5 月から 7 月にかけて, 樹洞抢よび大木調查と並行してアオバズクの生息可能性について 調査した。アオバズクは抱卵・育雛期の日中にオスが巣穴を見張 る習性を持つことや, 特徵的な糞をすることから, 日中に巣穴周 辺を調査すれば生息の可能性が明らかにできる ${ }^{18)}$ 。一部の樹林で は，夜間に鳴き声を頼りにした生息調査をおこなった。

\section{（2）環境情報}

2000 年 10 月撮影の地上分解能 $4 \mathrm{~m}$ の高分解能衛星 IKONOS の画像から, 画像解析ソフト ER mapper (Earth Resource Mapping 社)をむちいて, 教師つき分類によって樹冠とそれ以外 の部分を分けて樹冠分布図を作成した（図一 1 )。作成した樹冠 分布図は GIS ソフトArc View 8.2（ESRI 社）をむちいて，以 下の他の環境条件と重㸚合わせた。

市街地については環境省作成の自然環境 GIS の土地被覆分類 項目の市街地・工業地, 拈よび緑の多い住宅地のうち（公園緑地 あ含まれる）公園・緑地部分は除いた区域を市街地としてもちい た（図一 1 )。

大木抢よび樹洞を有する木については, 現地調査結果を GIS に入力して, 上記の樹冠分布図抢よび市街地分布図に重㸚合わせ て作成した（図一 1 )。

\section{(3) 分析方法}

生息環境適合度モデルの作成にはロジスティック回帰分析をむ ちいた。ロジスティック回帰分析はある事象が起こる確率を求め る回帰分析で, 二值变数で表される生態学的現象によく当てはま ると言われている ${ }^{8)}$ 。橋本・夏原の手法 ${ }^{3)}$ に倣い, 読み取り範囲 の異なるロジスティック回帰モデルを複数作成し, 最も当てはま りの良いモデルを選択する方式をとった。

アオバズクが生息している木扔よび樹洞はあるがアオバズクの 生息していない木からそれぞれ半径 $100 \mathrm{~m}, 250 \mathrm{~m}, 500 \mathrm{~m}$ のバッ ファを発生させ，その円内に含まれる環境情報（樹冠面積, 市街 地面積, 大木数, 樹洞を有する木の数) を読み取った。最大読み 取り半径は冨田 ${ }^{18}$ が報告した最大行動距離 $500 \mathrm{~m}$ を根拠にした。

環境情報の独立変数は互いに相関が高いものを同じモデルに入 れないようにした。同一半径における環境情報間の積率相関係数 を求め, 相関係数の絶対值が 0.5 を超える変数がある場合は, ア オバズクにとって意味が強いと考えられる指数を残し, ほかの変 数を除いた。このようにして得られた環境情報を $P=0.2$ を变数 の取捨の基準とするステップワイズ法をもちいたロジスティック 回帰分析により，これらの環境条件の中からどれが变数として選 ばれるかを調べた。なお，本研究ではアオバズクの生息に必要な 樹林面積を明らかにしたいため, 樹冠面積は必ずモデルに含まれ るようにした。ロジスティック回帰分析には SAS (SAS Institute 社）を利用した。半径 $100 \mathrm{~m}, 250 \mathrm{~m}, 500 \mathrm{~m}$ の読み取り半径 ごとにモデルを作成し，これらの中で赤池の情報量基準 (AIC) が最小のモデルを最む当てはまりの良いモデルとして採用した。

\section{3. 結果}

\section{(1) 現地調査の結果}

大木は計 289 本，樹洞を有する木は計 92 本（胸高幹周 $300 \mathrm{~cm}$ 未満屯含む）記録した（図－1）。調査範囲東側の山中はくまな
く調査できてはいないが，針葉樹の人工林や尾根筋のシイ若齢林 にはほとんど大木はないので，見落としは少ないと思われる。

14 地点のアオバズクの生息地を発見した。生息場所は稀少性 に鑑み図示することは避けるが，広い意味での山裾における生息 地が 5 例, 都市の孤立緑地に打ける生息地が 9 例であった。内訳 は，確実な営巣木が 6 件，親鳥の生息を確認した地点が 6 件，特 徽的な糞痕の発見が 2 件であった。確実な営巣木の樹種の内訳は, クスノキ 2 本, スダジイ 1 本, ムクノキ 1 本, アカマッ 1 本, ク ロマッ 1 本であった。親鳥を観察した地点㧍よび粪痕を発見した 地点から最む近い樹洞を有する木を便宜的に営巣木として, 以降 の解析を抢こなった。

樹洞はあるがアオバズクの生息していない木は 78 本となるが, アオバズクはなわばりを持つため，今回は便宜的に営巣木とした 地点から半径 $250 \mathrm{~m}$ 以遠の樹洞はあるがアオバズクの生息しない 木である計 15 本を分析対象とした。

\section{(2) 読み取った変数間の相関}

同一読み取り半径における各独立変数間の積率相関係数を表一 1 に示した。各独立变数間で相関係数の絶対值が 0.5 を超えた半 径 $250 \mathrm{~m}$ 内㧍よび半径 $500 \mathrm{~m}$ 内の樹冠面積と市街地面積は, 本研 究がアオバズクの生息に必要な樹林面積に興味があることから, それぞれ樹冠面積のみを分析に使用する变数とした。

\section{（3）ロジスティック回帰分析の結果}

ロジスティック回帰分析の結果を表 -2 に示した。赤池の情報 量基準が最小のモデルである半径 $100 \mathrm{~m}$ 内の環境情報を読み取っ たモデルを採用した。説明变数には, 必ず含まれるように設定し た樹冠面積のほか, 市街地面積が選択された。

樹洞を有する木から半径 $100 \mathrm{~m}$ 内の樹冠面積および市街地面積 率とアオバズクの生息確率との関係は図－2のグラフで表すこと ができ，樹冠面積が増加するにつれ生息確率は高くなり，市街地 面積が増加するほど生息確率は低下する。今回得られたモデルで は, 市街地面積の負の影響が非常に強く, 半径 $100 \mathrm{~m}$ 内に市街地 が全く含まれない場合は樹洞を有する木が 1 本あるだけで生息確 率が 0.5 となった。アオバズクの生息確率が 0.5 を超えるために 必要な半径 $100 \mathrm{~m}$ 内の樹冠面積は, 市街地面積率が $10 \%$ の時は $2,900 \mathrm{~m}^{2}$, 市街地面積率が $20 \%$ の時は $6,900 \mathrm{~m}^{2}$, 市街地面積率が $30 \%$ の時は 9,100 $\mathrm{m}^{2}$, 市街地面積率が $40 \%$ の時は $12,200 \mathrm{~m}^{2} 2$, 市 街地面積率が $50 \%$ の時は $15,300 \mathrm{~m}^{2}$ となった。なお, グラフ上で は回帰曲線が途中で途切れているが，これは読み取り円内の面積 から設定した市街地面積を引いた面積を樹冠面積の最大值として いるためである。しかし, 実際には市街地にある街路樹等の樹冠 あ計測しているため, これを超えることあある。

表 -1 同一読み取り半径における各変数間の積率相関係数 $(n=29)$ 。括弧内は有意水準の $P$ 值を示す。

\begin{tabular}{|c|c|c|c|}
\hline & 樹冠面積 & 市街地面積 & 大木数 \\
\hline \multicolumn{4}{|l|}{ 半径100 m } \\
\hline \multicolumn{4}{|l|}{ 樹冠面積 } \\
\hline 市街地面積 & $-0.494(0.006)$ & & \\
\hline 大木数 & $0.302(0.111)$ & $-0.133(0.490)$ & \\
\hline 樹洞を有する木の数 & $0.228(0.233)$ & $0.006(0.974)$ & $0.472(0.010)$ \\
\hline \multicolumn{4}{|l|}{ 半径250 m } \\
\hline \multicolumn{4}{|l|}{ 樹冠面積 } \\
\hline 市街地面積 & $-0.546(0.002)$ & & \\
\hline 大木数 & $0.082(0.672)$ & $-0.383(0.041)$ & \\
\hline 樹洞を有する木の数 & $0.005(0.979)$ & $-0.014(0.943)$ & $0.355(0.059)$ \\
\hline \multicolumn{4}{|l|}{ 半径500 m } \\
\hline \multicolumn{4}{|l|}{ 樹冠面積 } \\
\hline 市街地面積 & $-0.782(0.000)$ & & \\
\hline 大木数 & $-0.164(0.395)$ & $-0.399(0.032)$ & \\
\hline 樹洞を有する木の数 & $-0.214(0.265)$ & $0.139(0.472)$ & $0.207(0.281)$ \\
\hline
\end{tabular}


表 -2 読み取り半径別に得られたロジスティック回帰モデルの説明変数の係数と赤池の情報量基準 AIC の比較 $(n=29)$ 。偏回帰係数 の下の括弧内の值は Wald 検定による $P$ 值。分析から除いた変数は横線を入れた。

\begin{tabular}{|c|c|c|c|c|c|c|}
\hline & 定数項 & 樹冠面積 $\left(\mathrm{m}^{2}\right)$ & 市街地面積 $\left(\mathrm{m}^{2}\right)$ & 大木数 & 樹洞を有する木 & AIC \\
\hline \multirow[t]{2}{*}{ 半径 $100 \mathrm{~m}$} & 0.2698 & 0.000132 & -0.00013 & & & 32.481 \\
\hline & $(-0.8739)$ & $(0.2109)$ & $(0.0241)$ & & & $(0.0231)$ \\
\hline \multirow{2}{*}{ 半径 $250 \mathrm{~m}$} & -3.0418 & 0.000033 & - & & 0.3780 & 35.885 \\
\hline & $(0.0204)$ & $(0.0688)$ & & & $(0.1540)$ & $(0.0751)$ \\
\hline \multirow[t]{2}{*}{ 半径500 m } & -1.9182 & 0.000005 & - & & 0.1029 & 39.359 \\
\hline & $(0.0661)$ & $(0.1786)$ & & & $(0.1782)$ & $(0.1900)$ \\
\hline
\end{tabular}

図ー 3 にモデルから予測された生息確率別に分けた地点数に対 して実際にアオバズクが生息していた地点数の割合を示した。予 測された生息確率が 0.25 から 0.5 の間抒よび 0.5 から 0.75 の間 において,実際の生息率は理想的な在・不在の比率とは異なった。 今回得られたモデルによる全体の正答率（overall prediction success）は 0.69 であり, 在・不在モデルの評価指標の 1 つであ る Cohen's kappa の值 ${ }^{20)}$ は 0.37 であった（表一 3 )。

\section{4. 考察}

\section{（1）モデルの妥当性}

今回得られたモデルの全体の正答率は 0.69 とまずまずであっ たが, Cohen's kappa の值は 0.37 と低いものであった（表一 3 ）。 Cohen's kappa には統計的な有意水準はないが, 異なる解析方法 による在・不在モデル間に打けるモデルの評価や比較も可能な良 い指標とされ，モデルの医学的応用では 0 から 0.4 の值をとるモ デルが “slight to fair (取るに足らないあのからまずまずの)”, 0.4 から 0.6 が “moderate (並の)”, 0.6 から 0.8 が “substantial (十分な)”, 0.8 から 1.0 が “almost perfect (ほぼ完全な)”モデ ルとされる7)。したがって, Cohen's kappa の值からは今回得ら れたモデルはやや予測性の劣るモデルと判断される。

このような結果になった原因として，まずサンプル数が少なかっ たことが考えられる。特にロジスティック回帰分析は稀に起こる 事象を予測する統計手法であるため, 今回のようにサンプル数が 29 と少ない上に約半数の 14 地点が生息地点というサンプルセッ トであったことには問題が残った。しかしアオバズクが生息可能 な樹洞を単位にモデルを作成する必要があったため, やむをえな いあのであった。二值変数の解析手法には他に判別分析や分類樹 があるが，統計上の条件を満たせば，単一種の分布予測には確率 で表されるモデルの方が情報量が多く有用であると筆者らは考え ている。

別の原因として, 営巣していないとした樹洞の内部形状がアオ バズクの営巣が可能なものでなかった可能性がある。この点につ いては詳細に調べられた報告はなく, 今後の研究を待つしかない。

今回，予測值が 0.5 以上であるにも関わらず生息していなかっ た地点の 1 つは, かつての営巣木 (現在は樹洞のあった枝が折れ ている）から $150 \mathrm{~m}$ 以内であり，また隣接する生息地から来た之 考えられる個体がこの木から $150 \mathrm{~m}$ 以内にまで夜間飛来していた。 また別の予測が外れて生息していなかった 1 地点の予測值は 0.504 と僅かに 0.5 を超えただけであり, 予測值が 0.5 を下回っ たあののアオバズクが生息していた 6 地点のうちの 3 地点は 0.47 以上であった。

\section{（2）アオバズクの生息環境}

あっとも当てはまりの良かったモデルの読み取り半径 $100 \mathrm{~m}$ は 比較的狭いが，アオバズクが特定の止まり木の周辺でフライキャッ チングによる狩りをすること ${ }^{18)}$ からあ納得がいくあのである。た だし，ヒナの成長につれて餌を大量に確保する必要があるために 行動圈は半径 $100 \mathrm{~m}$ 以上を超えることもあるようだ(16),18)。

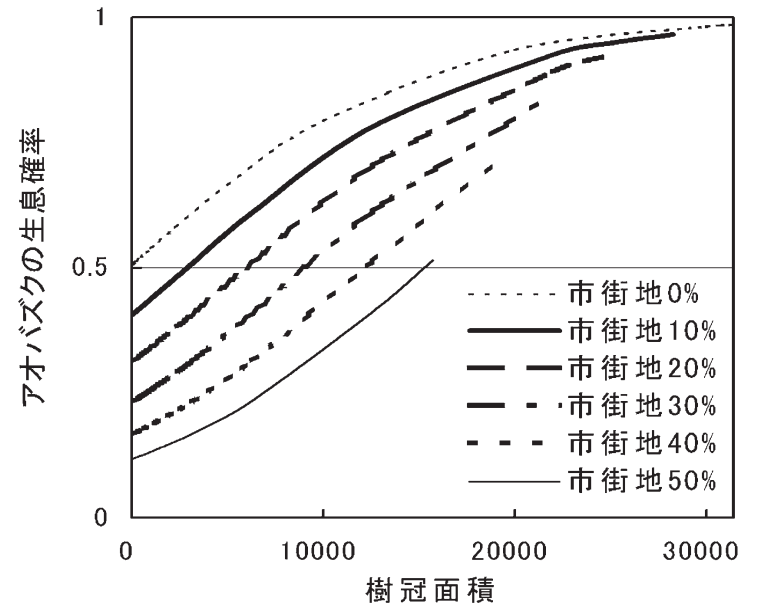

図－２樹洞を有する木から半径 $100 \mathrm{~m}$ 内の樹冠面積 $\left(\mathrm{m}^{2}\right)$ ，市 街地面積率（\%) とアオバズクの生息確率との関係

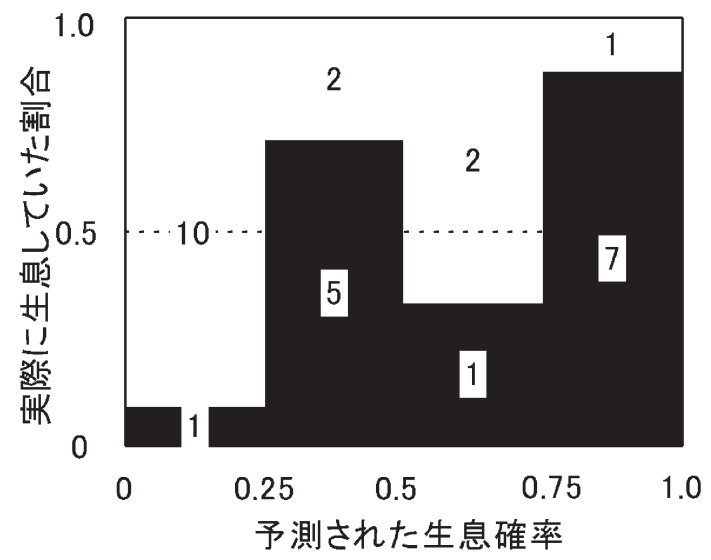

図ー3 モデルから予測された生息確率別に分けた地点数に対す る実際にアオバズクが生息していた地点数の割合。（図 中の数字は地点数）

\begin{tabular}{|c|c|c|c|c|}
\hline & & \multicolumn{2}{|c|}{ 実際 } & \multirow[t]{2}{*}{ 正答率 } \\
\hline & & + & - & \\
\hline \multirow[t]{4}{*}{ 予測 } & + & 8 & 3 & 0.73 \\
\hline & - & 6 & 12 & 0.67 \\
\hline & \multicolumn{3}{|c|}{ Overall prediction success } & 0.69 \\
\hline & \multicolumn{3}{|c|}{ Cohen's kappa } & 0.37 \\
\hline
\end{tabular}

今回得られたモデルでは, 負の要因としての市街地の影響が非 常に強かった。本種は街灯に集まる昆虫を効率的に捕食している ことが観察されることから, 本種は市街地に適応した種ではない かとバードゥオッチャーの間では言わ枦ことあある。しかし， 
静岡市の例 ${ }^{12)}$ では人口が集中する DID 地区内では DID 地区外の 社寺林よりも大面積の樹林でしかアオバズクの生息が認められな かったことからも, 市街地面積は本種の生息にとって負の要因で ある。今回の調査地の中でも, 繁華街に近く, 観光客で賑わう神 社では, 樹洞を有する木は数本あったがアオバズクの生息は認め られなかった。一方で緑地之住宅地の境の車の往来の少ない道路 上に張り出した樹冠で巣穴を見張るアオバズクの親鳥の姿む観察 した。市街地はアオバズクの主な慨となる甲虫の発生源でないこ とや，人による干渉が負の要因となっていると考えられる。

今回得られたモデルによれば, 半径 $100 \mathrm{~m}$ 内に市街地が含まれ ない状態で樹洞を有する木が 1 本あれば生息確率は 0.5 を超える。 実際，農村地域では水田や畑に囲まれた孤立木に打ける営巣も稀 ではなく ${ }^{11)}$ ，本種の生息は樹林の規模に依存しないではないかと あ言われることがある。市街地では餌は発生しないが, 農地では 餌となる蛾や甲虫が発生するため，十分な慨が確保できるのかも しれない。ただし今回作成したモデルの調查範囲には農村地域を 含んでいないので区外推定である。今回の生息地の中で最小の半 径 $100 \mathrm{~m}$ 内の樹冠面積は $0.78 \mathrm{ha}$ であったが，糞痕のみの記録で あり, 確実な営巣木加ら半径 $100 \mathrm{~m}$ 内の最小樹冠面積は $1.07 \mathrm{ha}$ （市街地面積率は０％）であった。今回のモデルの適用範囲を考 慮すると, アオバズクの生息環境の保全には, 樹洞を有する木か ら半径 $100 \mathrm{~m}$ 以内に少なくとも $1.1 \mathrm{ha}$ のまとまった樹林が必要だ と言える。ただし, 市街地に隣接していると餌場が減り, また特 に巣立ち直後の幼鳥は人との緩衝帯が必要になる あう少し多くの樹林面積が必要となってくるのだと考えられる。

今回の解析は植生タイプを考慮していない。しかし, 本種の営 巣木の樹種はスダジイとケヤキの 2 種が大半を占めると報告され ているが ${ }^{11}$, 今回発見した確実な営巣木の樹種は常緑広葉樹 2 種, 落葉広葉樹 1 種, 常緑針葉樹 2 種の計 5 種と多様であった。また, 営巣木周囲の植生夕イプも, 常緑広葉樹林や落葉広葉樹林, マッ 林であり, 多様であった。アオバズクの餌となる大型甲虫の力ミ キリムシ類にはそれぞれの植生タイプごとに発生する種がいるた め $^{5)}$, 植生夕イプの違いによる餌の発生量に大きな差はないと考 えられるが，この点については現在調査中である。

\section{（３）アオバズクの保全に向けて}

アオバズクの保全にはまず営巣可能な樹洞の保護が重要である。 基本的にアオバズクが営巣可能な樹洞は大木にあるため, 大木を 有する樹林の保全が重要である。京都市街地において二レ科樹種 を中心之した大木や樹林は社寺境内や旧屋敷跡等の歴史的な土地 に多く残存しているが沾)，樹林としてまとまって残存している面 積は一部の大きな神社で 4.0ha 以上と大きく，寺院でも 1 ha 以 上の規模のものが多く存在し, 小規模な神社では孤立木状態のこ とが多い(19)。大小自体は市街地の中に屯点在し, 信仰の対象と屯 なっているため，ある程度保全されていると言って良いだろう。 しかし近年, 社寺に扔いても建て増しや駐車場整備等によって樹 林としての保全が危ぶまれる事態が起きている。また, 大木を腐 朽の進行から守る目的やスズメバチが巣を作ることを防ぐ目的で 樹洞が塞がれることがある。樹洞はアオバズクに限らず，多くの 小動物の住処である ${ }^{2)}$ 。樹洞を有する大木と今回得られたモデル によって導き出されるアオバズクの生息に必要な樹林面積を保全 することによって，アオバズクの保全のみならず，都市に扔いて 生物多様性保全の核となる緑地を確保することができるだろう。

謝辞 : 京都府立医科大学の山野聡子氏には現地調査に御協力頂い た。アオバズクの生息調查に関して, 京都大学大学院理学系研究 科の冨田良雄博士, 日本野鳥の会京都支部の長谷川美奈子氏から 助言を頂いた。大阪府立大学大学院農学生命科学研究科の田端敬 三氏加ら下鴨神社境内の, 環境省国民公園京都御苑管理事務所の
木村博司所長から御苑内の巨樹デー夕を頂いた。清水建設(株)の 小松義典博士には衛星画像の前処理をして頂いた。京都大学大学 院農学研究科のアロン・イスガー氏には英文を見て頂いた。また 本研究は平成 13 年度日本生命財団環境研究助成（代表：森本幸 裕）を受けた研究成果の一部である。記して謝意を表します。

\section{補注・引用文献}

1）江崎保男・和田岳（2001）：近畿地区鳥類レッドデータブック：京都 大学出版会, $225 \mathrm{pp}$

2 ）橋本啓史（2002）：樹木のウ口之小鳥の住処：「NHK 趣味悠々・樹木 ウオッチング」(森本幸裕)：NHK 出版, 58-59

3 ）橋本啓史・夏原由博（2002）：ロジスティック回帰をもちいた都市に おけるシジュウカラの生息環境適合度モデル：ランドスケープ研究 65, 539-542

4) Higuchi, H. and Morishita, E. (1999) : Population declines of tropical migratory birds in Japan : Actinia 12, 51-59

5 ) 小島圭三・岡部正明 (1960)：日本産カミキリムシ食樹総覽：弘文堂 書店, $330 \mathrm{pp}$

6 ）京都府企画環境部（2002）：京都府レッドデータブック 2002一上・野 生生物編一: 京都府, $935 \mathrm{pp}$

7) Manel, S., Williams, H. C. and Ormerod, S. J. (2001) : Evalua ting presence-absence models in ecology -the need to account for prevalence- : Journal of Applied Ecology 38, 921-931

8 ) Morrison, L. M., Marcot, B. G. and Mannan, R. W. (1998) : Wildlife-habitat relationships: The University of Wisconsin Press, $458 \mathrm{pp}$

9 ）村上健太郎・松井理恵・前中久行・森本幸裕（2003）：京都市内孤立 林に打けるシダ植物の種組成と微地形との関係：ランドスケープ研究 66(5), 513-516

10）村上健太郎・森本幸裕（2000）：京都市内孤立林に打ける木本植物の 種多様性とその保全に関する景観生態学的研究：日本緑化工学会誌 25(4), 345-250

11）日本野鳥の会茨城支部（2000）: 平成 12 年度指定鳥獣保護調查報告書一 フクロウ科鳥類の生息分布及び繁殖状況に関する調査一：茨城県, $37 \mathrm{pp}$

12）日本野鳥の会静岡支部（1982）：静岡市におけるアオバズクの分布と 生息環境：Strix 1, 93-102

13）野口和恵（2002）：香川県におけるアオバズク Ninox scutulata の営 巣状況之食性：香川生物 $29,39-44$

14）林野庁 (1957)：野鳥之巣箱：林野庁

15）坂本圭児・吉田博宣（1986）：都市域におけるニレ科樹林（木）の残 存とその形態：造園雑誌 49(5), 131-136

16）谷口一夫（1983）：繁殖期におけるアオバズク Ninox scutulata の残 し慨について：鳥 32, 145-152

17）富沢 章（2001）：アオバズクが捕食する昆虫について-「落とし餌」 からの検討 : : Strix 19, 121-127

18）冨田良雄（1991）：アオバズクを追ってーアマチュア写真家の生態観 察一: 自費出版, $50 \mathrm{pp}$

19）吉田博宣・坂本圭児（1987）：市街地に掞ける土地利用と二レ科樹林 （木）の残存形態ならびに残存過程：造園䧱誌 50(5), 78-83

20) Cohen's kappa は, 全サンプル数を n, 予測が十で実際が十のサンプ ル数を $\mathrm{a}$, 予測が十で実際がーのサンプル数を $\mathrm{b}$ ，予測がーで実際が 十のサンプル数を c, 予測がーで実際がーのサンプル数を $\mathrm{d}$ ， とする 時に以下の式で算出され，0から1の間の值を取り，正しい予測をす るモデルほど 1 に近い值となる。

$$
\frac{[(a+d)-(((a+c)(a+b)+(b+d)(c+d)) / n)]}{[n-(((a+c)(a+b)+(b+d)(c+d)) / n)]}
$$

